\title{
Emerging Technologies Landscape on Education. A review
}

\author{
Luis de-la-Fuente-Valentín, Aurora Carrasco, Kinga Konya, and Daniel Burgos \\ UNIR Research, International University of La Rioja, Paseo de la Castellana 163, Madrid, Spain
}

\begin{abstract}
This paper presents a desk research that analysed available recent studies in the field of Technology Enhanced Learning. The desk research is focused on work produced in the frame of FP6 and FP7 European programs, in the area of Information and Communication Technologies. It concentrates in technologies that support existing forms of learning, and also in technologies that enhance new learning paradigms. This approach includes already adopted and successfully piloted technologies. The elaboration of the desk research had three main parts: firstly, the collection of documents from CORDIS and other institutions related to TEL research; secondly, the identification of relevant terms appearing in those documents and the elaboration of a thesaurus; and thirdly, a quantitative analysis of each term occurrences. Many of the identified technologies belong to the fields of interactive multimedia, Human-computer Interaction and-or related to recommendation and learning analytics. This study becomes a thorough review of the current state of these fields through the actual development of R\&D European projects. This research, will be used as a basis to better understand the evolution of the sector, and to focus future research efforts on these sectors and their application to education.
\end{abstract}

Keywords - Interactivity, Multimedia, R\&D European projects, ICT and learning, emerging technologies

\section{INTRODUCTION}

$\mathrm{T}$ rends and hot research topics in a specific field are reflected on the research areas promoted by public and private funding programs. This is the case of the Framework Programs launched by the European Commission that "bundles all research-related EU initiatives together under a common roof playing a crucial role in reaching the goals of growth, competitiveness and employment" [35]. Therefore, the identification of the most repeated research topics in projects funded by FP6 and FP7 leads to the identification of the most relevant research topics in Europe since 2002. The work presented in this document focuses on the educational field, and aims to identify the most relevant technologies that have impacted and will impact education in the near future. It is part of HoTEL, a European project that will provide a methodological framework to increase the impact of technological innovations in the educational field.

The desk research is focused on work produced in the frame of FP6 and FP7 programs (projects and Networks of
Excellence), in the area of Information and Communication Technologies (ICT). The identified trends have been complemented by those mentioned in related works such as the reports published by the Institute for Prospective Technological Studies (IPTS), and the Horizon Reports produced by the New Media Consortium (NMC). The result is a landscape of the currently most relevant research topics in Technology Enhanced Learning (TEL), and the areas of learning in which these technologies are being applied.

Being one of the goals of this paper the identification of already adopted technologies for learning, we have reviewed the existing literature in order to identify those aspects of TEL that are considered effectively adopted or planned to be adopted in the near future. In particular, we have focused on review studies from the IPTS, who gathered their information from experts workshops, field consultations and desk research. Thus, they provide a complete view of current state of TEL in the European countries.

Another aim of this paper is to identify those technologies that will impact future education. For this purpose, we have focused the analysis of the different editions of the Horizon Report (i.e. Higher education, K-12 and museums) produced by the NMC.

This document is structured as follows, Section II describes the methodology used to perform the desk research and Section III presents the thesaurus used as reference. Sections IV, 0 and VI analyse the information from different perspectives: research trends, research areas and application learning areas, respectively. Section VI.H elaborates on the analysed Networks of Excellence (NoE). Next, Section depicts the future applications of the presented study and,finally, Section VIII presents the conclusions of the study.

\section{METHODOLOGY}

\section{A. Data Sources}

This desk research is aimed at identifying technologies enhancing new forms of learning, specially focusing on the research produced in the frame of EU funded programmes. However, for the elaboration of this document we have also considered other information sources.

In particular, we have analysed the EU research projects and NoEs funded by the FP6 and FP7 programs, and studies and reports from the IPTs and the NMC. 


\section{1) FP6 and FP7 projects}

As stated in [35], the CORDIS repository stores information about research projects funded by the European Union which are carried out by European, research institutions such as commercial organizations, research institutes and universities.

The CORDIS repository stores the project information once the agreement has been signed, and, if there is a change in the contract, updates the stored information upon specific request. The records remain in the repository after the project has ended. Not all projects contain the same set of information fields, however, there is an overall homogeneity that allows bulk retrieval and classification of projects information.

\section{2) FP6 and FP7 Networks of Excellence (NoE)}

Information about NoEs is stored and structured in CORDIS in the same way as in the case of the projects. However, a NoE project should not be strictly considered as a research project. Therefore, NoEs have been analysed separately from projects, and they are described in order to complement the conclusions extracted from FP6 and FP7 projects.

\section{3) Institute for Prospective Technological Studies (IPTS)}

The IPTS is one of the seven scientific institutes of the European Commission's Joint Research Centre (JRC). The studies carried out by the IPTS lead to the publication of reports, which are focused on specific scientific and technical issues. These reports (around 700) are publicly available for consultation, being some of them quite aligned with the goal of this desk research. Therefore, they have been considered as one of the sources for our analysis.

\section{4) The New Media Consortium (NMC)}

For the sake of this desk research, the most popular report offered by NMC: the Horizon Report. Annually published, it is "a decade-long research project designed to identify and describe emerging technologies likely to have an impact on learning, teaching, and creative inquiry in higher education".

Since the objective of the Horizon Reports is quite aligned with the goal of this desk research, they have been considered as one of the sources of our analysis.

\section{B. Selection criteria}

\section{1) FP6 and FP7 projects and NoEs}

From all the FP6 and FP7 projects available for consultation at CORDIS $^{1}$, we have selected those particularly interesting in the field of Technology Enhanced Learning. At the CORDIS page, we used the simple search interface as follows:

- Search terms: education, TEL, learn, learning, teach, teaching, train, training and school

- Framework programme: FP6 and FP7 checked.

We reviewed the description of the found projects and discarded those that did not fit with the desk research goals. For example, the $3 D$ VIVANT project was in the results set, but it was discarded because it is not directly related to education. As a result of this manual review, 102 projects were selected.

\footnotetext{
${ }^{1}$ http://cordis.europa.eu/fp7/ict/projects/home_en.html
}

The collection of 102 projects used for this desk research contained 7 Networks of Excellence. In a second review round, we examined the project descriptions in more detail and assigned several keywords to each project. More details about the keywords assignment are given in subsection $\mathrm{C}$. As we read the project descriptions more carefully in this second round, more projects were discarded, containing the resulting set a total of 86 projects.

\section{2) Institute for Prospective Technological Studies}

From all the reports available at IPTS, we have focused on those regarding ICT and TEL. Therefore, we have filtered the number of documents by applying the criteria described as follows:

- Using the search engine provided at the web page [25], we have restricted the reports to those matching the keyword "ICT".

- Then, we have manually reviewed the project descriptions, and we have selected those that explicitly mention education.

- Finally, we have reviewed the reports given the summary of e-Learning related projects [26] and added them to our selection.

\section{3) The New Media Consortium}

In this desk research, we have used the NMC Horizon Reports to analyse trends and predictions on ICT and education. We considered the reports produced since 2009, because older reports are no longer relevant in the identification of trends.

\section{Analysis}

\section{1) FP6 and FP7 projects}

It was the authors' opinion that the Subjects field (a classification of projects on thematic areas provided by CORDIS) does not offer sufficient information of the project's research topics. For example, the ELEKTRA project aims at the development of an educational game, which is hardly outlined by its subjects (education, training - information processing, information systems-telecommunications).

Thus, the first task was to obtain a more descriptive set of keywords to summarize each project topics. This was manually done by the authors: firstly, reviewing the project description; secondly, writing keywords that matched with the description. A combination of the identified terms with the terms extracted from the IPTS and NMC reports resulted in the elaboration of a thesaurus that guided the classification of the research topics and the areas of learning they support, to be presented in Section III.

The identified NoEs have been separately discussed, and they are described in Section VII in order to complement the analysis of the projects.

\section{2) NMC and IPTS reports}

All NMC Horizon Reports follow the same structure: they choose six different technologies and classify them by the expected time for adoption. Three classifications are available: 
"one year or less", "two to three years" and "four to five years". For each identified technology, the report includes an executive description, a discussion of its relationship with education, and a collection of examples that use technology in the educational field. For the purpose of this desk research, we have compiled all the identified technologies in the reviewed reports, also considering its field of application (given by the report in which they appear) and the time period on which the prediction was made.

The IPTS reports do not follow such a fixed structure and the way the information is presented depends on the specific objective of the report and the project that frames the document. Thus, it is not possible to extract the information from these documents with the methodological approach adopted in the case of NMC. Due to this, and considering the nature of IPTS reports, they have been used to take note of the technologies they explicitly mention. In other words, to determine which technologies were considered relevant for their studies.

Information collected from both NMC and IPTS reports were used in Section IV to analyse research trends in the TEL field, and to perform a time based analysis of the TEL predictions.

\section{ICT THESAURUS USED AS REFERENCE}

During the analysis of the documentation, a number of technologies have been identified. In some cases, the same technology was mentioned using different terms, in other cases, different technologies are related among themselves so that they can be clustered in research areas. With all the identified terms and technologies, we have elaborated a thesaurus that classifies them by research topics and the areas of learning they support, finds synonyms and allows for a more systematic analysis. The thesaurus has been created as follows:

Firstly, the descriptions of all the selected FP6 and FP7 projects were manually reviewed, assigning them keywords. The keywords identified the main and secondary technologies used in the project, as well as the area of learning where the project applies. The reviewers were asked not to use a predefined set of keywords, but to be spontaneous. The technologies that appeared at IPTS and NMC reports were also considered, and this time the names were collected as they appeared in the documents. Note that the manual nature of the keywords selection could have introduced an involuntary bias on the study.

Then, synonyms were identified from all the keywords collected at the previous steps, reducing the number of available terms, and translating the spontaneous keywords assigned in the first step, into a collection of more formal terms. Finally, the related technologies and areas of learning were grouped into clusters. The creation of the clusters was guided by the research areas identified in all the reviewed documents and the expertise of the authors of the help desk.

The thesaurus, shown at appendix A, has been used for the classification of FP6 and FP7 research projects. It is divided in two main categories (technologies and areas of learning), which are divided into subcategories (also referred as clusters). The technologies related to Artificial Intelligence and Interactive Multimedia play a transversal role in the thesaurus. That is, these technologies are represented in most of the clusters, but there is no cluster specifically dedicated to them.

\section{TRENDS IN TECHNOLOGY ENHANCED LEARNING}

This section presents the review of the NMC and IPTS reports and the conclusions extracted from them. The reviewed documents can be classified in three types:

a) IPTS review reports: this type of documents usually review the existing examples and are focused on past research.

b) IPTS reports identifying trends: documents such as [29], [31] or [33] have the goal of identifying trends that will build the future of TEL.

c) NMC reports: the Horizon Report charts the landscape of emerging technologies and provides a complete collection of the technologies that are expected to impact education in future years.

The analysis resulted in Table I, which summarizes the occurrences of relevant keywords in the reports. In the table, each column represents one of the above mentioned document types, and each row refers to one of the clusters identified in the created thesaurus. Each cell's content determines whether or not a given cluster is mentioned in the corresponding type of documents. For example, the reference to [24] in the first row, second column, means that this document mentions one of the keywords belonging to the UC cluster. Mentions per document, are ordered in decreasing occurrence order per cluster. Giving an idea of the number of reports in which they appear, and their relevance in them.

Note that cells in the table may contain two or more references to the same document. This is because we placed one reference to the document for each different mentioned keyword. For example, document [4] mentions 'digital preservation' and 'electronic publishing', both classified into the CRT cluster, therefore, two occurrences of the reference to this document are in the corresponding cell.

If we consider a technology to be more relevant the more occurrences it has in the reports and the more number of documents where it is mentioned, three different behaviours appear on the table: (i) technologies relevant in past research, but not so relevant in the predictions; (ii) technologies that are as relevant in the past research as they are in the predictions; and (iii) technologies more relevant in the predictions than in past research.

The only cluster that might fall in (i) category is PA, which is mentioned in IPTS predictions but not in the Horizon Reports. In group (ii) we find WEB and SAS clusters. The relevance of web based systems in past TEL research cannot be denied, and the semantic web has counted with the support of the W3C. Finally, most of the clusters fall in (iii) category. 
TABLE I

MENTIONS TO THE IDENTIFIED CLUSTERS IN IPTS AND NMC REPORTS

\begin{tabular}{|c|c|c|c|}
\hline Clusters & $\begin{array}{c}\text { IPTS Review } \\
\text { Reports } \\
\text { (past) }\end{array}$ & $\begin{array}{c}\text { IPTS } \\
\text { Trend Reports } \\
\text { (future) }\end{array}$ & \begin{tabular}{|c|} 
NMC Horizon \\
Reports \\
(future)
\end{tabular} \\
\hline $\begin{array}{l}\text { Ubiquitous computing } \\
\text { (UC) }\end{array}$ & \begin{tabular}{|l|}
{$[30][30]$} \\
{$[24]$}
\end{tabular} & $\begin{array}{l}{[31][31][31]} \\
{[33][33]} \\
{[29]}\end{array}$ & \begin{tabular}{|l|}
{$[4][4][4]$} \\
{$[5][5][5]$} \\
{$[9][9][9]$} \\
{$[6][6]$} \\
{$[7][7]$} \\
{$[8][8]$} \\
{$[3][3]$} \\
{$[10]$} \\
{$[11]$} \\
{$[12]$} \\
{$[1]$} \\
{$[2]$}
\end{tabular} \\
\hline $\begin{array}{l}\text { Web } 2.0 \text { based tools and } \\
\text { systems (WEB) }\end{array}$ & \begin{tabular}{|l}
{$[24][24][24]$} \\
{$[13]$} \\
{$[30]$}
\end{tabular} & \begin{tabular}{|l}
{$[29][29][29][29]$} \\
{$[33][33][33]$}
\end{tabular} & $\begin{array}{l}7][7][7] \\
{[2][2]} \\
{[5][5]} \\
{[3]} \\
{[6]} \\
{[8]} \\
{[12]}\end{array}$ \\
\hline $\begin{array}{l}\text { Games and Virtual } \\
\text { Worlds (GVW) }\end{array}$ & \begin{tabular}{|l}
{$[30]$} \\
{$[24]$}
\end{tabular} & \begin{tabular}{|l}
$31][31][31]$ \\
{$[33][33]$} \\
{$[29][29]$}
\end{tabular} & \begin{tabular}{|l}
{$[2]$} \\
{$[6]$} \\
{$[9]$} \\
{$[10]$} \\
{$[11]$} \\
{$[12]$}
\end{tabular} \\
\hline Augmented reality (AR) & & \begin{tabular}{|l|}
$29]$ \\
{$[31]$} \\
{$[33]$}
\end{tabular} & \begin{tabular}{|l|}
{$[1]$} \\
{$[3]$} \\
{$[4]$} \\
{$[6]$} \\
{$[8]$} \\
{$[10]$} \\
{$[12]$}
\end{tabular} \\
\hline Other technologies (OT) & \begin{tabular}{|l}
$21]$ \\
{$[19]$}
\end{tabular} & \begin{tabular}{|l}
$33][33]$ \\
{$[23]$}
\end{tabular} & \begin{tabular}{|l|}
{$[11][11]$} \\
{$[1]$} \\
{$[10]$} \\
{$[12]$}
\end{tabular} \\
\hline $\begin{array}{l}\text { Human computer } \\
\text { interaction }(\mathbf{H C I})\end{array}$ & & \begin{tabular}{|l}
{$[31]$} \\
{$[33]$}
\end{tabular} & \begin{tabular}{|l|}
{$[1]$} \\
{$[3]$} \\
{$[6]$} \\
{$[8]$} \\
{$[9]$} \\
{$[10]$} \\
\end{tabular} \\
\hline $\begin{array}{l}\text { Access-to-content related } \\
\text { technologies }(\text { CRT })\end{array}$ & & \begin{tabular}{|l}
{$[29]$} \\
{$[31]$} \\
{$[33]$}
\end{tabular} & \begin{tabular}{|l|}
{$[4][4]$} \\
{$[1]$} \\
{$[2]$} \\
{$[3]$} \\
\end{tabular} \\
\hline Learning Analytics (LA) & & [33] [33] & \begin{tabular}{|l|}
{$[1]$} \\
{$[2]$} \\
{$[9]$} \\
{$[10]$} \\
{$[11]$}
\end{tabular} \\
\hline $\begin{array}{l}\text { Environments and } \\
\text { technologies for } \\
\text { collaboration }(\mathbf{C S C L})\end{array}$ & {$[30]$} & \begin{tabular}{|l|}
{$[29]$} \\
{$[33]$}
\end{tabular} & $\begin{array}{l}{[7][7]} \\
{[12]} \\
{[2]}\end{array}$ \\
\hline $\begin{array}{l}\text { Personalized, adaptive } \\
\text { technologies (PA) }\end{array}$ & {$[30]$} & \begin{tabular}{|l}
{$[31][31][31]$} \\
{$[33]$} \\
{$[29]$}
\end{tabular} & \\
\hline $\begin{array}{l}\text { Semantic-aware systems } \\
\text { (SAS) }\end{array}$ & {$[30][30]$} & {$[33]$} & $\begin{array}{l}{[5]} \\
{[8]}\end{array}$ \\
\hline
\end{tabular}

It is worth to mention the case of LA, AR and HCI. Such technologies have recently appeared in the TEL world, so they receive no mention in past TEL research. These clusters are highly related to artificial intelligence and interactive multimedia, which emphasizes the relevance of those technologies in the learning world. Surprisingly, CRT cluster has no presence at all in past research reviews. MOOCs and OpenCourseWare will definitively impact TEL research in the future years.

Artificial intelligence technologies play an important role in clusters such as UC, LA and SAS. This emphasizes their relevance in current research and in future trends. Also, interactive multimedia

\section{A. Time analysis of NMC predictions}

In this subsection we have visually represented the predictions made by NMC reports in a time line, in order to determine how they evolved over the years. We provide three different figures: one for higher education, another one $\mathrm{f}$ or K12 education (the US equivalent to the 'schools' area of learning), and the last one for museums.

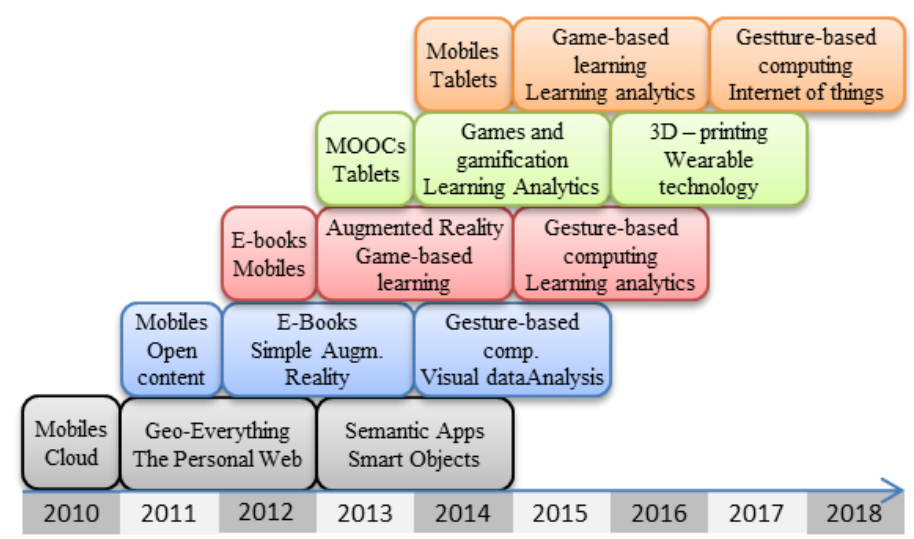

Fig. 1: NMC predictions for higher education

Fig. 1 shows the predictions for higher education. The following observations can be made:

- Since 2009, mobiles adoption is expected to occur in "one year or less". The prediction is repeated year by year but the goal does not seem to be achieved. In the last two editions of the report, 'mobiles' are being replaced by 'tablets'.

- Learning analytics appeared in the 2011 report and, since then, they are expected to have an impact on higher education sooner or later. The same can be said about games.

- Massive Open Online Courses suddenly appeared in the 2013 report, and are expected to have a clear and immediate impact in higher education.

- The 2013 report introduces new and interesting concepts, such as 3D-printing and wearable technology.

From Fig. 2, which shows the predictions for $\mathrm{K}-12$, the following observations can be made:

- Mobiles are expected to be adopted, but the prediction is less "aggressive" than in higher education. However, it seems to be an always live promise.

- Game based learning is expected to play a relevant role in $\mathrm{K}-12$ education. This is coherent with Section VI.A.1). 


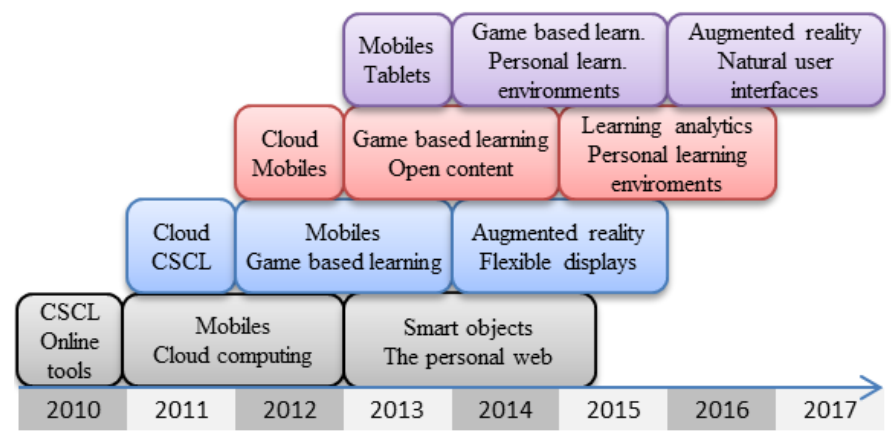

Fig. 2: NMC predictions for K-12

From Fig. 3, which shows the predictions for museums, the following observations can be made:

- Innovative methods to interact with the information are subject of research. Thus, augmented reality, gesturebased computing and natural user interfaces are expected to be adopted. This is consistent with Section VI.I.

- As it happened in higher education and $\mathrm{K}-12$, mobiles are expected to be adopted in the next year (since 2010), but the goal does not seem to get accomplished.

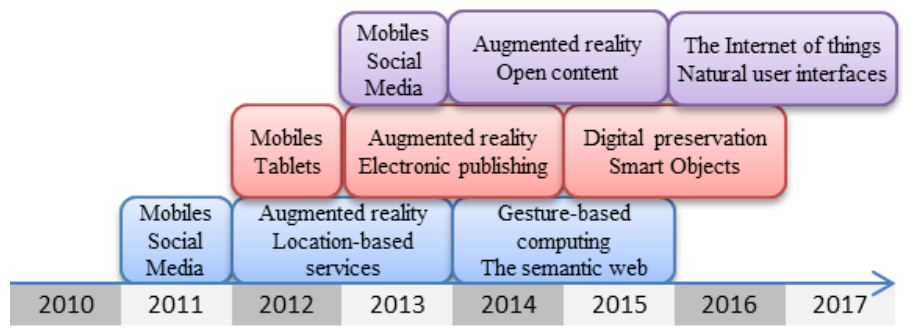

Fig. 3: NMC predictions for museums

The above analysis emphasizes how interactive multimedia is expected to impact the learning world, mainly by means of educational games and augmented reality. Also, artificial intelligence is essential part of learning analytics and is therefore expected to be widely used in higher education and other areas of learning.

\section{V.ICT RESEARCH AT FP6 AND FP7}

In this section, we first provide a quick overview of the topics researched in the projects funded by the European Commission within the FP6 and FP7 programs and, after that, we present a cluster-by-cluster analysis based on the thesaurus of Section III.

A first approach to determine the most frequent research topics in the analysed projects was to study the most repeated terms in the project summaries provided by CORDIS. However, the analysis revealed that the most relevant words were 'learning, project', 'knowledge, research', 'support' and 'technology', being therefore difficult to get an overview of the research topics with this method.

The second approach was to analyse the most repeated terms in the manually assigned keywords, which were selected from the thesaurus. The resulting set contains much more technology related terms, and it is therefore more feasible to obtain a quick overview of the most relevant technologies. The terms that appear the most are shown in

TABLE II. It can be seen that technologies related to learning games, content management, interfaces, collaborative environments or semantic analysis (just to mention a few) are frequent topics in FP6 and FP7 research projects, and therefore play a relevant role in recent research on Technology Enhanced Learning.

TABLE II

MOST REPEATED KEYWORDS IN REVIEWED PROJECTS

\begin{tabular}{|l|l|l|l|l|l|}
\hline \multicolumn{1}{|c|}{ Term } & $\#$ & \multicolumn{1}{c|}{ Term } & $\#$ & \multicolumn{1}{c|}{ Term } & $\#$ \\
\hline $\begin{array}{l}\text { semantic-aware } \\
\text { technologies }\end{array}$ & 11 & $\begin{array}{l}\text { human computer } \\
\text { interaction }\end{array}$ & 5 & $\begin{array}{l}\text { learning } \\
\text { standards }\end{array}$ & 4 \\
\hline Games & 10 & $\begin{array}{l}\text { context-aware } \\
\text { systems }\end{array}$ & 5 & grid computing & 4 \\
\hline $\begin{array}{l}\text { learning } \\
\text { management } \\
\text { systems }\end{array}$ & 9 & $\begin{array}{l}\text { personalized } \\
\text { content } \\
\text { presentation }\end{array}$ & 5 & $\begin{array}{l}\text { content } \\
\text { repositories }\end{array}$ & 4 \\
\hline $\begin{array}{l}\text { collaborative } \\
\text { environments }\end{array}$ & 7 & web 2.0 & 4 & augmented reality & 4 \\
\hline social networks & 5 & $\begin{array}{l}\text { personal learning } \\
\text { environments }\end{array}$ & 4 & mobile devices & 4 \\
\hline
\end{tabular}

Table III shows the most repeated keywords within the different identified clusters. A project may be related to different clusters, and thus can contain keywords associated to several of them. As a consequence, the table allows the identification of how clusters are related among themselves. Next subsections give an overview of each cluster and depict their mutual relationships. For presentation purposes, some of the keyword lists in Table III have been truncated.

\section{A. Web 2.0 based tools and systems (WEB)}

The traditional web, based on static HTML pages and with no chances for interaction, experienced a big change with the widespread use of technologies that allowed dynamic generation of web content. With such approach, the users became able to interact with the web, easily writing and publishing their own content. Then, the traditional web shifted to the web 2.0. Such change also impacted educational systems, so that learners were able to interact with the content and with peers. The "web 2.0 based tools and systems" cluster refers to those learning technologies whose typical interface is web based, designed or not for educational purposes.

According to Table III, the keywords in this cluster show that projects related to WEB are also related to SAS (7 occurrences of 'semantic-aware technologies'), UC (4 occurrences of 'mobile devices', 3 of 'context-aware systems'). LA and PA are also related to the WEB cluster.

\section{B. Ubiquitous computing (UC)}

Ubiquitous (or pervasive) computing refers to a type of human-computer interaction where the information processing is integrated into everyday objects and activities. The term ubiquitous computing was coined by Mark Weiser in 1988, and the topic has received much attention since then. 
Ubiquitous computing is related to distributed computing, mobile computing, sensor networks, human-computer interaction, and artificial intelligence. There are many ways in which information can interact with people. For example, from a non-intrusive perspective, ambient displays may react to events by changing their decoration; another example could be the TV volume automatically turned down when a visit enters the living room.

Ubiquitous learning refers to the support of anytimeanywhere learning, that is, when the specific goal of the ubiquitous technology is to support the learning process. Intuitively, this technology fits with informal learning approaches, but also applies to formal learning strategies such as shifting the classroom, or activities involving different spatial locations.

Table III shows how the UC cluster is quite related to PA (2 occurrences of 'personalized content presentation') and WEB (2 occurrences of 'social networks').

\section{C.Augmented reality $(A R)$}

Our lives are increasingly surrounded by technology, and it is difficult to think of a daily task that is not supported by any device or gadget. We use computers for work and leisure, and we communicate with others by using smartphones which integrate a lot of functionalities. In this scenario we can use the displays of our devices to view the real world, but another interesting usage is to augment our view of the real word by mixing such view with elements drawn by the computer. Such mixture of the real world with virtual elements, only visible through the corresponding display, is what we call augmented reality.

Such technology has been exploited in games, e-commerce and also learning. The information that we capture with our senses can be enhanced with augmented reality techniques, with the corresponding impact in the learning process.

Projects in the AR cluster are quite related to HCI, with occurrences of 'human-computer-interaction', 'haptic devices' and 'gesture-computing'. Keywords such as 'immersive virtual worlds' or 'simulations' also reveal a kind of overlapping with the GVW cluster.

\section{D.Access-to-content related technologies (CRT)}

Before the digital revolution that came with the Internet, the production of educational content was hardly affordable by teachers, who used textbooks created and sold by third parties. However, digital content is easier to create and, more important, easier to reuse. Reusability of learning content increases the efficiency of the authoring process, so the definition of methods for an efficient creation, distribution and use of learning content has been on hot topic in educational research.

Content repositories store large amounts of learning objects, which can be used to compose new and richer learning objects. Interoperability among repositories enables a more agile distribution of such learning objects. Such agile distribution of content required new copyright strategies, compatible with the surrounding technology. Thus, in 2002 the OpenCouseWare initiative (course lessons created at universities and freely published via the Internet) was launched at the MIT and was soon reinforced by the launch of similar projects at different universities. Also, the Creative Commons license defined the copyleft (as opposed to copyright), that provided legal mechanisms to authors to allow free access to their content. The last step towards such open culture is the MOOC movement (Massive Open Online Courses), consisting on online courses (not only content) freely offered via the web. MOOC is one of the current buzzwords in educational research.

Personalization and adaptation, possibly enabled by semantic analysis, are promoted by the large availability of learning content. Thus, the CRT cluster is mainly related to SAS, PA and WEB.

\section{E. Human computer interaction (HCI)}

Human-computer Interaction (HCI) involves the study, planning, and design of the interaction between people (users) and computers. It is often regarded as the intersection of computer science, behavioural sciences, design and several other fields of study. Strictly speaking, HCI research brings on innovative computer interfaces, including new way of presenting the information and new ways to introduce human's input.

The HCI cluster is quite related to AR, with 2 occurrences of 'augmented reality'.

\section{F. Learning Analytics (LA)}

While we interact with computers, we produce large amounts of information that can be stored and processed. The analysis of such information has been used in fields such as ecommerce to determine the customers' personal habits, and vendors use this technique to offer them personal recommendations, usually aimed at increasing the benefits.

As computers enter in the educational world, learners' activities can be traced and stored and this fact enables the use of the abovementioned analysis techniques. Thus, learning analytics is defined as the measurement, collection, analysis and reporting of data about learners and their contexts, for purposes of understanding and optimizing learning and the environments in which it occurs.

According to Table III, the LA cluster is mainly related to WEB and GVW. However, LA is so recent in the TEL field that not so many projects have been funded in the topic. As a result, there is no meaningful overlap with other clusters.

\section{G. Games and Virtual Worlds (GVW)}

The term virtual world is largely used as a synonym of 3-D virtual environment. In such environments, the user plays the role of an avatar and "lives" inside this world. Virtual worlds have evolved from simple text-based interfaces to rich 3-D environments that allow for an immersive user experience, where a real person interacts with objects in computer simulated environments. 
Virtual worlds provide means to augment or enhance the way we receive information and have received the interest of educational researchers. In them, interaction with peers is an important part of the environment, so they enable the collaborative and cooperative learning strategies. User engagement in the virtual world can be achieved by gamification techniques, thus enabling serious games to be developed for educational purposes.

Projects aimed at the research of educational game are also usually complemented by very different technologies. As a result, GVW cluster is related to almost all other clusters in the proposed thesaurus.

TABLE III

KEYWORD OCCURRENCES GROUPED BY CLUSTER

\begin{tabular}{|c|c|c|c|c|c|c|c|c|c|c|c|c|c|c|c|c|c|}
\hline \multicolumn{2}{|l|}{ LA } & \multicolumn{3}{|c|}{ GVW } & \multicolumn{4}{|c|}{ CSCL } & \multicolumn{4}{|l|}{ WEB } & \multicolumn{2}{|l|}{ CRT } & \multicolumn{2}{|l|}{ PA } & \\
\hline $\begin{array}{l}\text { information } \\
\text { visualization }\end{array}$ & 3 & \multicolumn{2}{|c|}{ Games } & \multicolumn{4}{|c|}{\begin{tabular}{|l|l|} 
collaborative \\
environments
\end{tabular}} & \multicolumn{4}{|c|}{$\begin{array}{l}7 \begin{array}{l}\text { learning management } \\
\text { systems }\end{array} \\
\end{array}$} & 8 & content repositories & 4 & \begin{tabular}{|l|} 
learning management \\
systems (WEB)
\end{tabular} & 5 & \\
\hline learning analytics & 3 & \multicolumn{2}{|c|}{$\begin{array}{l}\text { immersive virtual } \\
\text { worlds }\end{array}$} & \multicolumn{4}{|c|}{\begin{tabular}{|l|}
$\begin{array}{l}\text { computer supported } \\
\text { collaborative learning }\end{array}$ \\
\end{tabular}} & 2 & \multicolumn{3}{|c|}{$\begin{array}{l}\text { semantic-aware } \\
\text { technologies (SAS) }\end{array}$} & 7 & open source content & 3 & $\begin{array}{l}\text { personalized content } \\
\text { presentation }\end{array}$ & 5 & \\
\hline social networks (WEB) & 1 & \multicolumn{2}{|c|}{ simulations } & \multicolumn{4}{|c|}{$2 \begin{array}{l}\text { online communication } \\
\text { tools }\end{array}$} & 2 & \multicolumn{3}{|l|}{ social networks } & 5 & digital preservation & 3 & $\begin{array}{l}\text { semantic-aware } \\
\text { technologies (SAS) }\end{array}$ & 4 & \\
\hline social media (WEB) & 1 & \multicolumn{2}{|c|}{ Mobiles (UC) } & \multicolumn{4}{|c|}{1 tactile interfaces $(\mathrm{HCl})$} & 1 & \multicolumn{3}{|c|}{ mobile devices (UC) } & 4 & $\begin{array}{l}\text { semantic-aware } \\
\text { technologies (SAS) }\end{array}$ & 2 & $\begin{array}{l}\text { personal learning } \\
\text { environments }\end{array}$ & 4 & \\
\hline $\begin{array}{l}\text { online applications for } \\
\text { teaching (WEB) }\end{array}$ & 1 & \multicolumn{2}{|c|}{$\begin{array}{l}\text { information } \\
\text { visualization (LA) }\end{array}$} & \multicolumn{4}{|c|}{$\begin{array}{l}1 \\
\text { semantic-aware } \\
\text { technologies (SAS) }\end{array}$} & 1 & \multicolumn{3}{|c|}{ learning standards } & 4 & $\begin{array}{l}\text { personalized content } \\
\text { presentation (PA) }\end{array}$ & 2 & $\begin{array}{l}\text { collaborative } \\
\text { environments (CSCL) }\end{array}$ & 3 & \\
\hline $\begin{array}{l}\text { learning management } \\
\text { systems (WEB) }\end{array}$ & 1 & \multicolumn{2}{|c|}{$\begin{array}{l}\text { content repositories } \\
\text { (CRT) }\end{array}$} & \multicolumn{4}{|c|}{$\begin{array}{l}\text { information } \\
\text { visualization (LA) }\end{array}$} & \multicolumn{4}{|c|}{1 web 2.0} & 4 & grid computing (WEB) & 2 & electronic tutors & 3 & \\
\hline Games (GVW) & 1 & \multicolumn{2}{|c|}{$\begin{array}{l}\text { adaptive learning } \\
\text { system (PA) }\end{array}$} & \multicolumn{4}{|c|}{ electronic tutors (PA) } & \multicolumn{4}{|c|}{1 grid computing } & 4 & web interfaces (WEB) & 1 & web 2.0 (WEB) & 2 & \\
\hline data mining & 1 & virtua & al environments & 1 & $\begin{array}{l}\text { attentio } \\
\text { manage }\end{array}$ & $\begin{array}{l}n \\
\text { men }\end{array}$ & $n t(P A)$ & 1 & $\begin{array}{l}\text { context-aware } \\
\text { systems (UC) }\end{array}$ & & & 3 & $\begin{array}{l}\text { super rich online } \\
\text { repositories }\end{array}$ & 1 & Games (GVW) & 2 & \\
\hline $\begin{array}{l}\text { virtual environments } \\
\text { (GVW) }\end{array}$ & 1 & tactile & e interfaces $(\mathrm{HCl})$ & 1 & $\begin{array}{l}\text { artificial } \\
\text { (PA) }\end{array}$ & inte & elligence & 1 & learning analyti & ics & (LA) & 3 & serious games (GVW) & 1 & adaptive content & 2 & \\
\hline student monitoring & 1 & $\begin{array}{l}\text { stude } \\
\text { (LA) }\end{array}$ & nt monitoring & 1 & $\begin{array}{l}\text { ubiquitc } \\
\text { (UC) }\end{array}$ & us c & computing & 1 & $\begin{array}{l}\text { personal learnir } \\
\text { environments ( }\end{array}$ & $\begin{array}{l}\text { ing } \\
\text { (PA) }\end{array}$ & & 3 & $\begin{array}{l}\text { semantic } \\
\text { interoperability (SAS) }\end{array}$ & 1 & $\begin{array}{l}\text { emotion-aware } \\
\text { systems }\end{array}$ & 2 & \\
\hline $\begin{array}{l}\text { semantic-aware } \\
\text { technologies (SAS) }\end{array}$ & 1 & social & I networks (WEB) & 1 & Telepres & senc & & 1 & Interoperability & & & 3 & $\begin{array}{l}\text { learning standards } \\
\text { (WEB) }\end{array}$ & 1 & $\begin{array}{l}\text { context-aware } \\
\text { systems (UC) }\end{array}$ & 2 & \\
\hline $\begin{array}{l}\text { multimedia content } \\
\text { (WEB) }\end{array}$ & 1 & Interf & faces $(\mathrm{HCl})$ & $1: s$ & social ne & etwo & orks (WEB) & 1 & $\begin{array}{l}\text { collaborative } \\
\text { environments ( }\end{array}$ & $(\mathrm{CSC}$ & & 3 & content creation & 1 & & & \\
\hline mobile devices (UC) & 1 & $\begin{array}{l}\text { gestur } \\
\text { comp }\end{array}$ & $\begin{array}{l}\text { re based } \\
\text { uting }(\mathrm{HCl})\end{array}$ & 1 & $\begin{array}{l}\text { persona } \\
\text { environ }\end{array}$ & $\begin{array}{l}\text { Ilea } \\
\text { men }\end{array}$ & $\begin{array}{l}\text { arning } \\
\text { its (PA) }\end{array}$ & 1 & & & & & & & & & \\
\hline Interfaces $(\mathrm{HCl})$ & 1 & $\begin{array}{l}\text { emoti } \\
\text { systen }\end{array}$ & $\begin{array}{l}\text { ion-aware } \\
\mathrm{ms}(\mathrm{PA})\end{array}$ & $\left.1\right|_{1} ^{i}$ & $\begin{array}{l}\text { immers } \\
\text { worlds ( }\end{array}$ & $\begin{array}{l}\text { ive v } \\
\text { GVY }\end{array}$ & $\begin{array}{l}\text { virtual } \\
\text { W) }\end{array}$ & 1 & & & & & & & & & \\
\hline e-portfolio (WEB) & 1 & $\begin{array}{l}\text { collab } \\
\text { enviro }\end{array}$ & $\begin{array}{l}\text { Dorative } \\
\text { onments (CSCL) }\end{array}$ & 1 & & & & & & & & & & & & & \\
\hline $\begin{array}{l}\text { computer supported } \\
\text { collaborative learning } \\
\text { (CSCL) }\end{array}$ & 1 & $\begin{array}{l}\text { augm } \\
\text { (AR) }\end{array}$ & iented reality & 1 & & & & & & & & & & & & & \\
\hline UC & & & AR & & & & & & OT & & & & $\mathrm{HCl}$ & & SAS & & \\
\hline context-aware systems & & 5 & augmented realit & & & 4 & smart-tv & & & 1 & $\begin{array}{l}\text { hum } \\
\text { inter }\end{array}$ & & $\begin{array}{l}\text { computer } \\
\text { tion }\end{array}$ & $5 \begin{array}{l}s e \\
\mathrm{te}\end{array}$ & $\begin{array}{l}\text { emantic-aware } \\
\text { echnologies }\end{array}$ & & 11 \\
\hline mobile devices & & 4 & $\begin{array}{l}\text { human computer } \\
\text { interaction }(\mathrm{HCl})\end{array}$ & & & 2 & semantic $\mathrm{W}$ & veb & (SAS) & 1 & gestu & ure & based computing & $3 \begin{array}{l}\text { le } \\
\text { sy }\end{array}$ & $\begin{array}{l}\text { earning management } \\
\text { ystems (WEB) }\end{array}$ & & 4 \\
\hline ubiquitous computing & & 3 & $\begin{array}{l}\text { immersive virtual } \\
(\text { GVW) }\end{array}$ & wo & orlds & 1 & context-aw & Iare & e systems (UC) & 1 & hapti & ic in & nterfaces & $2 \mathrm{tr}$ & ranslation technologies & & 2 \\
\hline $\begin{array}{l}\text { personalized content } \\
\text { presentation (PA) }\end{array}$ & & 2 & haptic interfaces & $(\mathrm{HC}$ & & 1 & wearable t & ech & nology & 1 & augn & nen & nted reality (AR) & $\mid \begin{array}{l}p \\
e\end{array}$ & $\begin{array}{l}\text { ersonal learning } \\
\text { environments (PA) }\end{array}$ & & 2 \\
\hline smart spaces & & 2 & $\begin{array}{l}\text { gesture based cor } \\
(\mathrm{HCl})\end{array}$ & & uting & 1 & Interfaces & (HC & & 1 & Inter & face & ces & 2 c & ontent repositories (CRT & & 2 \\
\hline social networks (WEB) & & 2 & Simulations (GVM & & & 1 & interactive & wh & iteboards & 1 & & & & & & & \\
\hline Mobiles & & 2 & $\begin{array}{l}\text { merge virtual and } \\
\text { worlds }\end{array}$ & & hysical & 1 & future class & sroc & om (UC) & 1 & & & & & & & \\
\hline pervasive computing & & 2 & enriched interfac & es ( & $(\mathrm{HCl})$ & 1 & ambient in & telli & ligence (UC) & 1 & & & & & & & \\
\hline pervasive technologies & & 2 & & & & & & & & & & & & & & & \\
\hline
\end{tabular}




\section{H.Environments and technologies for collaboration (CSCL)}

The ability to carry out an effective collaboration is a transversal skill that, thanks to constructivist learning approaches, receives lots of attention in the educational research world. Collaboration involves interaction between humans which is, by nature, quite unstructured. Such interaction can be supported by computers. When collaborative techniques are used to foster learning with the support of computers, we call it CSCL (Computer Supported Collaborative Learning).

The case of the CSCL cluster is similar to GVW. That is, projects in this cluster are also usually complemented by very different technologies, resulting in relationships with many other clusters. Among them, PA seems to present a stronger overlapping.

\section{Semantic-aware systems (SAS)}

In computer science, a semantic reasoner is a piece of software able to infer logical consequences from a set of asserted facts. These facts (called semantic metadata) are usually represented by a formal language such as RDF and refer to textual or multimedia objects stored in a repository, and to users' information.

In the educational field, semantic analysis research is oriented towards the understanding of natural human language (as opposite to computer languages) in order to provide better search mechanisms on learning content, and also to provide better interaction with computers.

The SAS cluster is related to WEB (4 occurrences of 'learning management systems'), PA and CRT.

\section{J. Personalized, adaptive technologies (PA)}

According to the learning styles theories, different students achieve learning with different methods, and prefer different content types. However, computer systems usually make no difference among users and present the same content to every student, structured in the same sequence, and offering the same interface.

The personalization and/or adaptation of the learning process may cover the different needs of the different students, so they can achieve learning in a more efficient manner.

The PA cluster is quite related to WEB (5 occurrences of 'learning management systems'), SAS (4 occurrences of 'semantic-aware technologies') and CSCL.

\section{K. Other technologies (OT)}

This cluster includes all those technologies that are somehow related to the analysed projects and documents, but have not been included in the defined clusters.

Not so many projects in this cluster have been funded by the FP6 and FP7 programs, however, it is interesting because it presents not so frequent emerging technologies, that can be promising for TEL research. For example, no project related to 3D printing have been found, while the last NMC report mentions such technology in its predictions.

Other interesting technologies are wearable interfaces (also related with UC cluster), or e-books as an innovative way to deliver learning material.

In this section, we depict the use of ICT in Education, in which technologies related to interactivity, multimedia, and artificial intelligence, become a mainstream in the application context. In Table III, we highlight the topics of highest relevance, in which semantics, collaboration, social networks, HCI, context-aware, web 2.0, and personalisation, combined, score 46 out of 85 , meaning a $54 \%$ of the total keywords. This combination of key concepts related to interactive multimedia and artificial intelligence become a major guideline for current and future research and development projects.

\section{AREAS OF LEARNING}

This section analyses the areas of learning to which the technology is being applied. In some projects the proposed system is aimed to a very specific field. For instance, the ELEKTRA project was focused on the development of a game to help teaching grade 8-level optics. On the contrary, the technology researched by other projects, such as E-LEGI, claims to be pedagogically neutral. That is, it could be used in any learning situation.

According to the thesaurus presented in Section III, six different areas of learning were identified:

- Formal education

- Non-formal learning

- Workplace learning

- Museums

- Unspecified field

- Others

The analysis presented in this section is based on

Table IV, which represents the cluster occurrences grouped by areas of learning, an asterisk at column $\mathrm{C}$, row $\mathrm{R}$, means that there is a project that research technological cluster $\mathrm{C}$, and applies to area of learning $\mathrm{R}$.

\section{A. Formal education}

Formal education corresponds to a systematic, organized education model, structured and administered according to a given set of laws and norms, presenting a rather rigid curriculum as regards objectives, content and methodology [36].

For the convenience of this study, we have divided the formal education learning area in three main parts: schools (primary education), secondary education, and higher education.

\section{1) Schools}

Table IV shows the list of projects that research technologies for schools. The most repeated cluster is GVW, related to games and virtual worlds, which seems logical, since games are used to increase learners' motivation and children are especially prone to like games. Therefore, games appear to be a promising technique to improve learning at schools. Another relevant technology for schools is human computer interaction 
(HCI). That is, new interfaces offer more intuitive interactions with computers, and allow children (not yet used to other interfaces) to learn more intuitively.

\section{2) Secondary education}

The most relevant technologies for secondary education are the Web and learning analytics. On the other hand, promising techniques such as augmented reality and human computer interfaces are not even mentioned, and there are only two occurrences of ubiquitous computing techniques. It could be argued that innovation in secondary education is limited by the classroom scenario, where mobile phones are in most cases not even allowed.

\section{3) Higher education}

In the case of higher education, the Web is the most researched technology, with personalization techniques playing a relevant role. Access-to-content technologies are also relevant in the field. This is logical since initiatives such as OpenCourseWare and MOOCs initially started at universities.

\section{B. Non-formal learning}

Educative processes endowed with flexible curricula and methodology, capable of adapting to the needs and interests of students, for which time is not a pre-established factor but is contingent upon the student's work pace, certainly do not correspond to those comprised by formal education, but fit into the so-called non-formal education [36].

Non-formal and informal education terms are frequently used indistinctly. Without entering in a debate of the appropriateness of each term, in this study we have identified that projects that focuses on informal learning are in fact related to what we have defined as non-formal learning. Thus, these two terms have been used indistinctly.

In the field of non-formal learning, the Web is the most researched technological cluster, and research on access to content technologies also plays a relevant role. It sounds logical since non-formal learners are usually intrinsically motivated to learn, so what they need is a good collection of learning materials (provided by the CRT cluster) and a method to interact with such material at their own pace (provided by the WEB).

\section{Workplace learning}

By 'workplace learning' we refer to those strategies applied by companies in order to allow their employees

TABLE IV

CLUSTER OCCURRENCES IN AREAS OF LEARNING

\begin{tabular}{|c|c|c|c|c|c|c|c|c|c|c|c|c|}
\hline & WEB & UC & AR & CRT & $\mathrm{HCl}$ & LA & GVW & CSCL & SAS & PA & OT & TOTAL \\
\hline Schools & $* *$ & $*$ & $*$ & $* *$ & $* * *$ & $*$ & $* * * * *$ & $* *$ & $* *$ & $* * *$ & $*$ & 23 \\
\hline Sec. Ed. & $* * * *$ & $* *$ & & $*$ & & $* * * *$ & $* * *$ & * & $* *$ & & * & 18 \\
\hline High. Ed. & $* * * * * *$ & $*$ & & $* * *$ & & $*$ & & $* *$ & $* * *$ & $* * * *$ & & 20 \\
\hline Non-formal & $* * * * * *$ & $* *$ & * & $* * *$ & & & * & $*$ & $*$ & $*$ & & 16 \\
\hline Workplace & $* * *$ & $*$ & & & & & $* *$ & $* * * *$ & $* *$ & $* * * * *$ & & 17 \\
\hline Museums & & $*$ & * & & $* *$ & $*$ & $* *$ & & & & & 7 \\
\hline Not specified & $* * * * * *$ & $* * *$ & * & $*$ & $* * *$ & $*$ & $* *$ & $* *$ & $* *$ & $* * * * *$ & $*$ & 27 \\
\hline Not exp. for learning & $* * * * * * *$ & $* * * * * * * *$ & $*$ & $* * * * *$ & $* * *$ & $*$ & & $*$ & $* * * *$ & & $*$ & 31 \\
\hline Other & $* * * * *$ & $*$ & $*$ & & $* * *$ & & $* * *$ & & $* *$ & $* * *$ & & 18 \\
\hline
\end{tabular}

\section{Workplace learning}

By 'workplace learning' we refer to those strategies applied by companies in order to allow their employees acquire new competences related to their position.

Environments for collaborative learning are the most researched technologies in this area of learning. Furthermore, this is the area of learning that gives more priority to collaboration technologies (CSCL). In other words, collaborative and cooperative skills are highly demanded at the workplace. On the other hand, personalization techniques are also relevant in this area.

\section{E. Museums}

Museums could be considered as a vehicle for non-formal or informal learning. However, the development of new methods to engage visitors by mixing leisure and information delivery has unique characteristics in museums, and several projects are aimed to this specific field. Thus, we have considered museums as an area of learning different to nonformal learning.

Few projects are explicitly devoted to research technology for museums. Among them, human computer interaction techniques and Virtual Worlds are the most relevant technological clusters. In museums, it is important to engage visitors, which requires innovative methods to interact with the exhibits, therefore, research is oriented toward this goal.

\section{F. Unspecific field}

The area of learning to which a project applies was determined by extracting such information from the project description, as published at CORDIS. However, there are 
some project descriptions in which such information is not explicitly stated, so we were not able to classify to which area of learning they belong. This group of 'unspecific field' projects, is divided in two subgroups: firstly, projects whose goal is explicitly oriented towards educational purposes, but do not state to which area of learning they belong. We have classified these projects as 'not explicit area of learning'. And secondly, projects that matched with the selection criteria, but are not explicitly aimed at educational purposes. We have classified these projects as 'not explicitly for learning.'

\section{1) Not explicit area of learning.}

This category is composed by projects regarding educational research, but that do not explicitly specifying to which area of learning they apply.

The Web is the most relevant researched technology in this type of projects. As it also happens in the higher education cluster, personalization techniques are researched as a way to improve the educational face of the web. It can be argued that those projects that do not explicitly state their area of application are generically designed, and can be adapted to different educational settings. It is therefore important to achieve a high degree of personalization and adaptation.

\section{2) Not explicitly for learning}

Some projects are related to technologies to might be applied to educational settings, but it is not explicitly stated on the project description. In those cases, we classified these projects as not explicitly for learning.

Ubiquitous computing (UC) is the hot research topic in this type of projects. Surprisingly, this topic has no major relevance in the rest of the areas of learning. It could be argued that ubiquitous computing is a promising research field, but it is not still clear how to apply it in educational settings.

\section{G. Workplace learning}

By 'workplace learning' we refer to those strategies applied by companies in order to allow their employees

\section{H.Workplace learning}

By 'workplace learning' we refer to those strategies applied by companies in order to allow their employees acquire new competences related to their position.

Environments for collaborative learning are the most researched technologies in this area of learning. Furthermore, this is the area of learning that gives more priority to collaboration technologies (CSCL). In other words, collaborative and cooperative skills are highly demanded at the workplace. On the other hand, personalization techniques are also relevant in this area.

\section{Museums}

Museums could be considered as a vehicle for non-formal or informal learning. However, the development of new methods to engage visitors by mixing leisure and information delivery has unique characteristics in museums, and several projects are aimed to this specific field. Thus, we have considered museums as an area of learning different to nonformal learning.

Few projects are explicitly devoted to research technology for museums. Among them, human computer interaction techniques and Virtual Worlds are the most relevant technological clusters. In museums, it is important to engage visitors, which requires innovative methods to interact with the exhibits, therefore, research is oriented toward this goal.

\section{J. Unspecific field}

The area of learning to which a project applies was determined by extracting such information from the project description, as published at CORDIS. However, there are some project descriptions in which such information is not explicitly stated, so we were not able to classify to which area of learning they belong. This group of 'unspecific field' projects, is divided in two subgroups: firstly, projects whose goal is explicitly oriented towards educational purposes, but do not state to which area of learning they belong. We have classified these projects as 'not explicit area of learning'. And secondly, projects that matched with the selection criteria, but are not explicitly aimed at educational purposes. We have classified these projects as 'not explicitly for learning.'

\section{1) Not explicit area of learning.}

This category is composed by projects regarding educational research, but that do not explicitly specifying to which area of learning they apply.

The Web is the most relevant researched technology in this type of projects. As it also happens in the higher education cluster, personalization techniques are researched as a way to improve the educational face of the web. It can be argued that those projects that do not explicitly state their area of application are generically designed, and can be adapted to different educational settings. It is therefore important to achieve a high degree of personalization and adaptation.

\section{2) Not explicitly for learning}

Some projects are related to technologies to might be applied to educational settings, but it is not explicitly stated on the project description. In those cases, we classified these projects as not explicitly for learning.

Ubiquitous computing (UC) is the hot research topic in this type of projects. Surprisingly, this topic has no major relevance in the rest of the areas of learning. It could be argued that ubiquitous computing is a promising research field, but it is not still clear how to apply it in educational settings.

\section{K. Other}

Finally, there are some cases where the project description states an educational purpose, but the application area does not fit to any of the previous criteria. Topics covered in this 'others' area of learning are digital libraries, social inclusion, conflict resolution, learners with specific needs, music institutions and educational curriculum.

It can be seen that music education puts emphasis on HCI technologies to improve learning. Another observation is that 
games are used as the vehicle that drives motivation in projects toward social inclusion.

\section{NETWORKS OF EXCELLENCE}

-AIM@SHAPE: by recognizing the relevance of multimedia objects (called shapes) in different application fields such as scientific simulations or edutainment, this $\mathrm{NoE}$ promoted semantic-based shape representations and semantic-oriented tools to acquire, build, transmit, and process shapes with their associated knowledge

- PROLEARN: this NoE worked in personalized adaptive learning and interactive media, with learning resources connected to real-world settings and reusable in different contexts. It investigated issues especially relevant for professional training in SME's and larger companies.

- MUSCLE: aims at harnessing the potential of machine learning for the automatic semantic annotation of multimedia content, creation of interfaces for the exploration of complex content, improvement of interoperability and exchangeability. This NoE also aims at the distribution of such technology to the stakeholders, such as educational institutions.

- KNOWLEDGE WEB: Supporting the transition process of Ontology technology from Academia to Industry is the main and major goal of this NoE. This is achieved by providing support to incorporate this technology, developing high-class education in the area of semantic web, and researching new uses of semantic web and web services.

- GaLA: This NoE that acknowledges the potential of serious games in the support of the learning process. It aims at the integration and harmonization of research activities across European institutions, as well as at the organization of joint research activities and the dissemination of serious games to support learning.

- IRIS: Interactive Storytelling is a major endeavour to develop new media which could offer a radically new user experience, with a potential to revolutionise digital entertainment. European research in Interactive Storytelling has played a leading role in the development of the field, and this creates a unique opportunity to strengthen its position even further by structuring some of its best actors within a Network of Excellence. IRIS (Integrating Research in Interactive Storytelling) aims at creating a virtual centre of excellence that will be able to achieve breakthroughs in the understanding of Interactive Storytelling and the development of corresponding technologies.

- STELLAR: represents the effort of the leading institutions and projects in European TEL to unify our diverse TEL community. This Network of Excellence is motivated by the need for European research on Technology-Enhanced Learning (TEL) to build upon, synergize and extend the valuable work we have started by significantly building capacity in TEL research within Europe, which is required to allow the European Union to achieve its goals via the Bologna Agreement and the execution of the Lisbon Agenda. The European TEL agenda has been set for the last 4 years by the Kaleidoscope network - with a huge strength in pedagogy and scientific excellence, and the Prolearn network with a complimentary strength in technical and professional excellence. We see integrating this excellence and moving on to the higher strategic formation of policy based in leading research is the challenge for the next three years. STELLAR will move beyond the earlier networks by setting a new and critical foresight agenda for TEL via an annually reviewed Grand Challenge programme.

\section{VIII.FUTURE WORKS AND APPLICATIONS}

The research presented in this paper is part of the HoTEL European project, a Support Action that will propose a methodological framework to support technological innovations in the educational field, speeding up the innovation cycle. The presented work is an exploratory research, the output of which will serve as the basis for an online consultation, and a number of interviews with acknowledged experts in the field. The overall goal is to better understand how innovation takes place in the learning world, and to elaborate a map of the most relevant technologies that will affect education in the near future. This research is focused on technologies. Next steps include the identification of innovative pedagogical approaches, and the creation of a grassroots innovators network that will benefit from the HoTEL innovation cycle.

\section{CONCLUSION}

This desk research has presented an analysis of the information from a total of 86 research projects and 7 Networks of Excellence funded by the European Union as part of the FP6 and FP7 programs. Also, we have considered the information from reports offered by the IPTS on the educational field, and the predictive Horizon Reports, produced by the NMC.

A detailed analysis of the compiled information has allowed to identify the most relevant technologies, and to produce clusters that group them by similarity. The following 11 different clusters were identified, many of them of the highest relevance to interactive multimedia and artificial intelligence:

1. Web 2.0 based tools and systems

2. Ubiquitous computing

3. Augmented reality

4. Access-to-content related technologies

5. Human computer interaction

6. Learning Analytics

7. Games and Virtual Worlds

8. Environments and technologies for collaboration

9. Semantic-aware systems

10.Personalized, adaptive technologies

11.Technologies that could not be grouped in any other 
cluster.

The analysis showed that web based technologies are the most funded topic within EU programs. Furthermore, they are usually researched in combination with other technologies such as semantic technologies or personalized learning content. In fact, in some cases it is not obvious at all to make a clear distinction among the different clusters. The analysis also shows the upcoming interest of ubiquitous computing on learning, especially via mobile and tablet computing. Another interesting conclusion is the irruption of learning analytics, an approach that has recently appeared and is gaining momentum rapidly. The analysis also revealed which technology combinations are more frequent. For example, the new interfaces suggested in the field of Human Computer Information are usually researched in combination with augmented reality techniques.

Another focus of the analysis was the identification of learning areas in which the researched technologies can be applied. The following 4 areas were identified:

- Formal education (including primary, secondary and higher education)

- Non-formal learning

- Workplace learning

- Museums

We also considered projects that do not apply to any explicit area of learning, and also projects that do not even explicitly apply to learning, but whose researched technologies are aligned with TEL research.

The analysis shows the relationship among areas of learning and technology clusters, for example, games are mainly researched for their application in schools, while computer supported collaboration is the preferred topic for workplace learning. Furthermore, a number of projects not explicitly for learning research ubiquitous computing technologies, so it is expected that such technologies will impact in the near future of TEL research.

The IPTS and NMC reports (a total of 34 reviewed documents) reveal predictions on what technologies will be used in the near future of education. It is worth to note how mobile computing is always expected to be immediately adopted, but never seems to be mature enough for an authentic usage. The most recent predictions introduce new and interesting concepts, such as 3D-printing, the Internet of Things, learning analytics, massive online open courses, augmented reality and wearable technology.

\section{ACKNOLEDGMENT}

This paper is being supported by the HOTEL Project (http://hotel-project.eu/, grant agreement 318530), funded by the Seventh Framework Programme of the European Commission, under the FP7 Programme-ICT-Call 8; and UNIR Research (http://research.unir.net), private research initiative which supports the Research Group on eLearning and Social Networks TELSOCK at the university.

\section{REFERENCES}

[1] L. Johnson, A. Levine, R. Smith, and S. Stone, "The 2010 Horizon Report," New Media Consortium, Austin, Texas, 2010.

[2] L. Johnson, S. Adams, and K. Haywood, "The 2011 Horizon Report K12 edition," The New Media Consortium, 2011.

[3] L. Johnson, S. Adams Becker, H. Witchey, M. Cummins, V. Estrada, A. Freeman, and H. Ludgate, "The NMC Horizon Report: 2012 Museum Edition.," Austin, Texas, 2012.

[4] L. Johnson, S. Adams, and H. Witchey, "The NMC Horizon Report: 2011 Museum Edition,” Austin, Texas, 2011.

[5] L. Johnson, A. Levine, and R. Smith, "The Horizon Report, 2009 Edition," New Media Consortium, Austin, Texas, 2009.

[6] L. Johnson, S. Adams, and M. Cummins, "NMC Horizon Report: 2012 K-12 Edition," Austin, Texas, 2012.

[7] L. Johnson, A. Levine, R. Smith, and T. Smythe, "The Horizon Report: 2009 K-12 Edition," The New Media Consortium, 2009.

[8] L. Johnson, H. Witchey, R. Smith, A. Levine, and K. Haywood, "The 2010 Horizon Report: Museum Edition,” Austin, Texas, 2010.

[9] L. Johnson, S. Adams, and M. Cummins, "The NMC horizon report: 2012 higher education edition," Austin, Texas, 2012.

[10] L. Johnson, R. Smith, H. Willis, A. Levine, and K. Haywood, "The 2011 Horizon Report," Austin, Texas, 2011.

[11] L. Johnson, S. Adams Becker, M. Cummins, V. Estrada, A. Freeman, and H. Ludgate, "NMC Horizon Report: 2013 Higher Education Edition," Austin, Texas, 2013.

[12] L. Johnson, R. Smith, A. Levine, and K. Haywood, "2010 Horizon Report: K-12 Edition.," Austin, Texas, 2010.

[13] Ala-Mutka, K. (2009). Review of Learning in ICT-enabled Networks and Communities.

[14] Ala-Mutka, K. (2010a). Discussions on Learning in Online Networks and Communities.

[15] Ala-Mutka, K. (2010b). Learning in Informal Online Networks and Communities.

[16] Ala-Mutka, K., Punie, Y., \& Redecker, C. (2008a). ICT for Learning, Innovation and Creativity.

[17] Ala-Mutka, K., Punie, Y., \& Redecker, C. (2008b). Digital Competence for Lifelong Learning.

[18] Ala-Mutka, Kirsti, Redecker, C., Punie, Y., Ferrari, A., Cachia, R., \& Centeno, C. (2010). The Future of Learning: European Teachers' Visions. Report on a foresight consultation at the 2010 eTwinning Conference. Seville.

[19] Bocconi, S., Kampylis, P., \& Punie, Y. (2012). Innovating Learning: Key Elements for Developing Creative Classrooms in Europe.

[20] Bogdanowicz, M., Burgelman, J. C., Gourova, E., \& Herrmann, C. (2002). Information and Communication Technologies.

[21] Cachia, R., Ferrari, A., Ala-Mutka, K., \& Punie, Y. (2010). Creative Learning and Innovative Teaching: Final Report on the Study on Creativity and Innovation in Education in EU Member States.

[22] Driessen, M., Emmerik, J. van, Fuhri, K., Nygren-Junkin, L., \& Spotti, M. (2011). CT Use in L2 Education for Adult Migrants - A qualitative study in the Netherlands and Sweden.

[23] Forge, S., \& Blackman, C. (2009). OLEDs AND E-PAPER - Disruptive potential for the European display industry.

[24] Huijboom, N., Broek, T. van den, Frissen, V., Kool, L., Kotterink, B., Nielsen, M. M., \& Miljard, J. (2009). Public Services 2.0: The Impact of Social Computing on Public Services.

[25] IPTS. (2013a). Scientific and Technical reports. Retrieved February 12, 2013, from http://ipts.jrc.ec.europa.eu/publications/index.cfm

[26] IPTS. (2013b). Summary of e-Learning related projects. Retrieved February 12, 2013, from http://is.jrc.ec.europa.eu/pages/EAP/eLearning.html

[27] Prato, G. De, \& Nepelski, D. (2013). Defining European ICT Poles of Excellence: A Literature Review.

[28] Prato, G. de, Nepelski, D., Szewczyk, W., \& Turlea, G. (2011). Performance of ICT R\&D.

[29] Punie, Y., Cabrera, M., Bogdanowicz, M., \& Zinnbauer, D. (2006). The Future of ICT and Learning in the Knowledge Society.

[30] Punie, Y., Zinnbauer, D., \& Cabrera, M. (2008). A Review of the Impact of ICT on Learning. 
International Journal of Artificial Intelligence and Interactive Multimedia, Vol. $2, N^{o} 3$.

[31] Rader, M., Boehle, K., Parodi, O., Dachs, B., Weber, M., Friedewald, M., Cremer, C., et al. (2008). European Perspectives on the Information Society: Annual Monitoring Synthesis and Emerging Trend Updates.

[32] Redecker, Christine, Haché, A., \& Centeno, C. (2010). Using Information and Communication Technologies to Promote Education and Employment Opportunities for Immigrants and Ethnic Minorities.

[33] Redecker, Christine, Leis, M., Leendertse, M., Punie, Y., Gijsbers, G., Kirschner, P., Stoyanov, S., et al. (2011). The Future of Learning: Preparing for Change.

[34] Redecker, Chrstine. (2012). The Use of ICT for the Assessment of Key Competences.

[35] Commision, E. (2013). CORDIS. Retrieved February 12, 2013, from http://cordis.europa.eu/guidance/about-projects_en.html

[36] Dib, C. Z. (1988). Formal, non-formal and informal education: concepts/applicability. AIP Conference Proceedings (Vol. 173, pp. 300315). AIP. doi:10.1063/1.37526
Dr. Luis de-la-Fuente-Valentín works as post-doctoral Senior Researcher UNIR. He is focused on the field of Technology-enhanced Learning, and a strong background in learning standards and specifications, learning analytics, information visualization, student centered learning systems, recomendations, mobile learning and gamification techniques. He works in European projects Intuitel and Hotel. He holds a $\mathrm{PhD}$ in Telematics Engineering

Aurora Carrasco works as Senior Project Manager at UNIR. She is Responsible for the R\&D Projects Office. She has deep experience in European and International Programme and Projects Management (e.g. EC EuropeAid, World Bank, FP7, LLP), and extensive knowledge of the EC's Project Cycle Management (PCM), and in the preparation of international project proposals, and offers. She holds degrees in Biology (BSc and MSc with major in Environment and Education)

Kinga Kónya works as Media Officer of Research \& Technology Projects at UNIR. She is responsible for the dissemination and communication of project objectives, research and development activities and results. In parallel, she works at the Postgraduate Department of UNIR. She holds a Bachelor's degree in French Studies (minor in Spanish Iberian-American Studies) and a Master's degree in International Economic Relations. She speaks Spanish, English, French and Hungarian.

Prof. Dr. Daniel Burgos works as Vice-chancellor for Research \& Technology, and Director of Engineering at the International University of La Rioja. He is or has been involved in a number of R\&D projects like, i.e. Intelleo, Hotel, Edumotion, Inspiring Science Education, EU-USR, Stellar, Gala, IntelLEO, Go-MyLife, Grapple, Unfold, ProLearn, TenCompetence, EU4ALL, NiHao, Kaleidoscope, Sister, ComeIn, Veritas, et cetera. He holds degrees in Communication (PhD), Computer Science (Dr. Ing), Education $(\mathrm{PhD})$, and Business Administration. 


\section{APPENDIX A: THESAURUS USED AS REFERENCE}

Categories Subcategories

Keywords

\begin{tabular}{|c|c|c|c|c|c|}
\hline \multirow{11}{*}{ Technologies } & $\begin{array}{l}\text { Web } 2.0 \text { based } \\
\text { tolos and systems } \\
(\mathrm{WEB})\end{array}$ & $\begin{array}{l}\text { web } 2.0 \\
\text { online communication tools } \\
\text { blogs } \\
\text { podcasting } \\
\text { eportfolio } \\
\text { accessible web content } \\
\text { e-portfolio }\end{array}$ & $\begin{array}{l}\text { multimedia content } \\
\text { web interfaces } \\
\text { widgets } \\
\text { integration } \\
\text { distributed open } \\
\text { infrastructure } \\
\text { linked data } \\
\text { service-oriented }\end{array}$ & $\begin{array}{l}\text { online applications for } \\
\text { teaching } \\
\text { learning management } \\
\text { systems } \\
\text { learning standards } \\
\text { interoperability } \\
\text { cloud computing } \\
\text { grid computing }\end{array}$ & $\begin{array}{l}\text { social networks } \\
\text { social media } \\
\text { foaf } \\
\text { online communities } \\
\text { social network analysis } \\
\text { social software }\end{array}$ \\
\hline & $\begin{array}{l}\text { Ubiquitous } \\
\text { computing (UC) }\end{array}$ & $\begin{array}{l}\text { ambient intelligence } \\
\text { internet of things } \\
\text { smart objects } \\
\text { location based services } \\
\text { ubiquitous computing }\end{array}$ & $\begin{array}{l}\text { intelligent contexts } \\
\text { pervasive } \\
\text { technologies } \\
\text { context-aware } \\
\text { systems } \\
\text { pervasive computing } \\
\text { smart spaces } \\
\end{array}$ & $\begin{array}{l}\text { mobiles } \\
\text { tablet computing } \\
\text { mobile apps } \\
\text { mobile devices }\end{array}$ & $\begin{array}{l}\text { mobile learning } \\
\text { geo-everything } \\
\text { creative classrooms } \\
\text { future classroom }\end{array}$ \\
\hline & $\begin{array}{l}\text { Augmented } \\
\text { reality (AR) }\end{array}$ & augmented reality & $\begin{array}{l}\text { simple augmented } \\
\text { reality }\end{array}$ & $\begin{array}{l}\text { merge virtual and } \\
\text { physical worlds }\end{array}$ & \\
\hline & $\begin{array}{l}\text { Access-to-content } \\
\text { related } \\
\text { technologies } \\
(\mathrm{CRT}) \\
\end{array}$ & $\begin{array}{l}\text { open source content } \\
\text { massively open online } \\
\text { courses } \\
\text { alternative licensing }\end{array}$ & $\begin{array}{l}\text { super rich online } \\
\text { repositories } \\
\text { electronic publishing } \\
\text { digital preservation } \\
\end{array}$ & $\begin{array}{l}\text { creative commons } \\
\text { opencourseware }\end{array}$ & $\begin{array}{l}\text { content repositories } \\
\text { content creation }\end{array}$ \\
\hline & $\begin{array}{l}\text { Human computer } \\
\text { interaction }(\mathrm{HCI})\end{array}$ & $\begin{array}{l}\text { human computer interaction } \\
\text { gesture based computing } \\
\text { natural user interfaces }\end{array}$ & $\begin{array}{l}\text { brain-machine } \\
\text { interfaces } \\
\text { 3-d holographic } \\
\text { displays } \\
\text { adaptable interfaces } \\
\end{array}$ & $\begin{array}{l}\text { haptic interfaces } \\
\text { enriched interfaces } \\
\text { interfaces }\end{array}$ & $\begin{array}{l}\text { tactile interfaces } \\
\text { voice interfaces }\end{array}$ \\
\hline & $\begin{array}{l}\text { Learning } \\
\text { Analytics (LA) }\end{array}$ & $\begin{array}{l}\text { data mining } \\
\text { big data and learning } \\
\text { analytics }\end{array}$ & $\begin{array}{l}\text { learning analytics } \\
\text { information } \\
\text { visualization }\end{array}$ & student monitoring & visual data analysis \\
\hline & $\begin{array}{l}\text { Games and } \\
\text { Virtual Worlds } \\
(\mathrm{GVW})\end{array}$ & $\begin{array}{l}\text { immersive virtual worlds } \\
\text { computer generated } \\
\text { simulations } \\
\text { simulation of physical, } \\
\text { chemical models } \\
\end{array}$ & $\begin{array}{l}\text { simulations for } \\
\text { training } \\
\text { virtual environments } \\
\text { simulations }\end{array}$ & $\begin{array}{l}\text { games } \\
\text { game-based learning }\end{array}$ & $\begin{array}{l}\text { serious games } \\
3 \mathrm{~d} \text { virtual worlds }\end{array}$ \\
\hline & $\begin{array}{l}\text { Environments } \\
\text { and technologies } \\
\text { for collaboration } \\
(\mathrm{CSCL})\end{array}$ & $\begin{array}{l}\text { collaborative environments } \\
\text { computer supported } \\
\text { collaborative learning }\end{array}$ & telepresence & $\begin{array}{l}\text { online communication } \\
\text { tools }\end{array}$ & sincronous learning \\
\hline & $\begin{array}{l}\text { Semantic-aware } \\
\text { systems (SAS) }\end{array}$ & $\begin{array}{l}\text { semantic web } \\
\text { metadata generation }\end{array}$ & $\begin{array}{l}\text { natural language } \\
\text { processing } \\
\text { semantic-aware } \\
\text { technologies }\end{array}$ & $\begin{array}{l}\text { semantic } \\
\text { interoperability }\end{array}$ & translation technologies \\
\hline & $\begin{array}{l}\text { Personalized, } \\
\text { adaptive } \\
\text { technologies } \\
\text { (PA) }\end{array}$ & $\begin{array}{l}\text { virtual mentors } \\
\text { electronic tutors } \\
\text { realtime assessment } \\
\text { monitors } \\
\text { artificial intelligence } \\
\end{array}$ & $\begin{array}{l}\text { attention management } \\
\text { adaptive content } \\
\text { smart learning content } \\
\text { adaptive learning } \\
\text { system }\end{array}$ & $\begin{array}{l}\text { personalized content } \\
\text { presentation } \\
\text { recommender systems } \\
\text { the personal web }\end{array}$ & $\begin{array}{l}\text { personal learning } \\
\text { environments } \\
\text { roleswitching } \\
\text { emotion-aware systems }\end{array}$ \\
\hline & $\begin{array}{l}\text { Other } \\
\text { technologies } \\
(\mathrm{OT})\end{array}$ & $\begin{array}{l}\text { flexible displays } \\
\text { smart-tv }\end{array}$ & $\begin{array}{l}\text { e-books } \\
\text { 3d printing }\end{array}$ & interactive whiteboards & wearable technology \\
\hline \multirow{6}{*}{$\begin{array}{l}\text { Areas of } \\
\text { learning }\end{array}$} & Formal education & \multicolumn{2}{|c|}{ secondary education } & Schools & \\
\hline & $\begin{array}{l}\text { Non-formal } \\
\text { learning }\end{array}$ & \multicolumn{2}{|l|}{ domestic learners } & informal learning & lifelong learning \\
\hline & $\begin{array}{l}\text { Workplace } \\
\text { learning }\end{array}$ & \multicolumn{2}{|c|}{ industry } & workplace & training \\
\hline & Museums & \multicolumn{2}{|l|}{ museum } & & \\
\hline & Unspecific field & $\begin{array}{l}\text { not explicitly for } \\
\text { learning }\end{array}$ & not specified & & \\
\hline & Other & $\begin{array}{l}\text { music institutions } \\
\text { digital library }\end{array}$ & $\begin{array}{l}\text { learner with special needs } \\
\text { educational curriculum }\end{array}$ & conflict resolution & social inclusion \\
\hline
\end{tabular}


International Journal of Artificial Intelligence and Interactive Multimedia, Vol. 2, $N^{o} 3$.

APPENDIX B: LIST OF REVIEWED PROJECTS

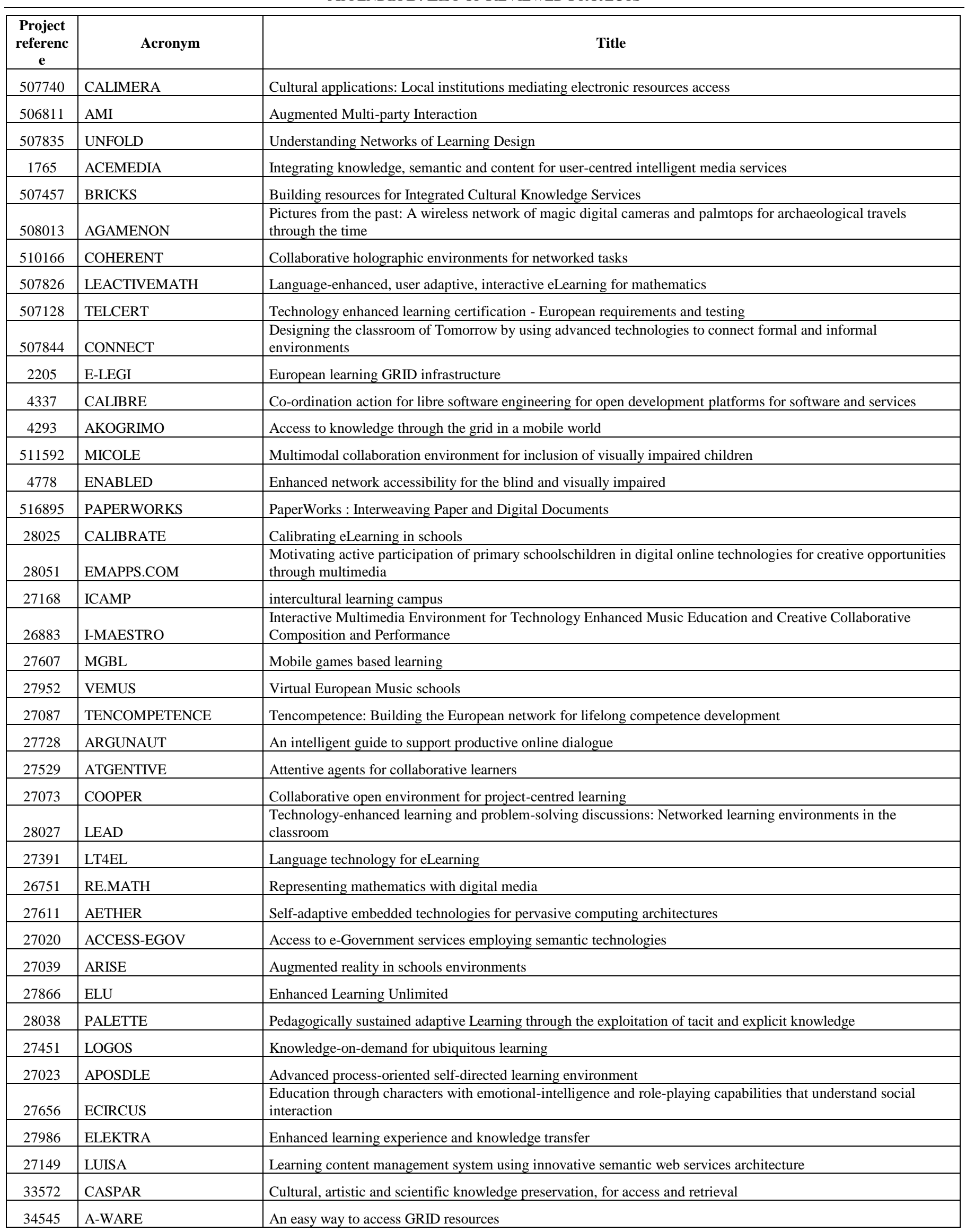




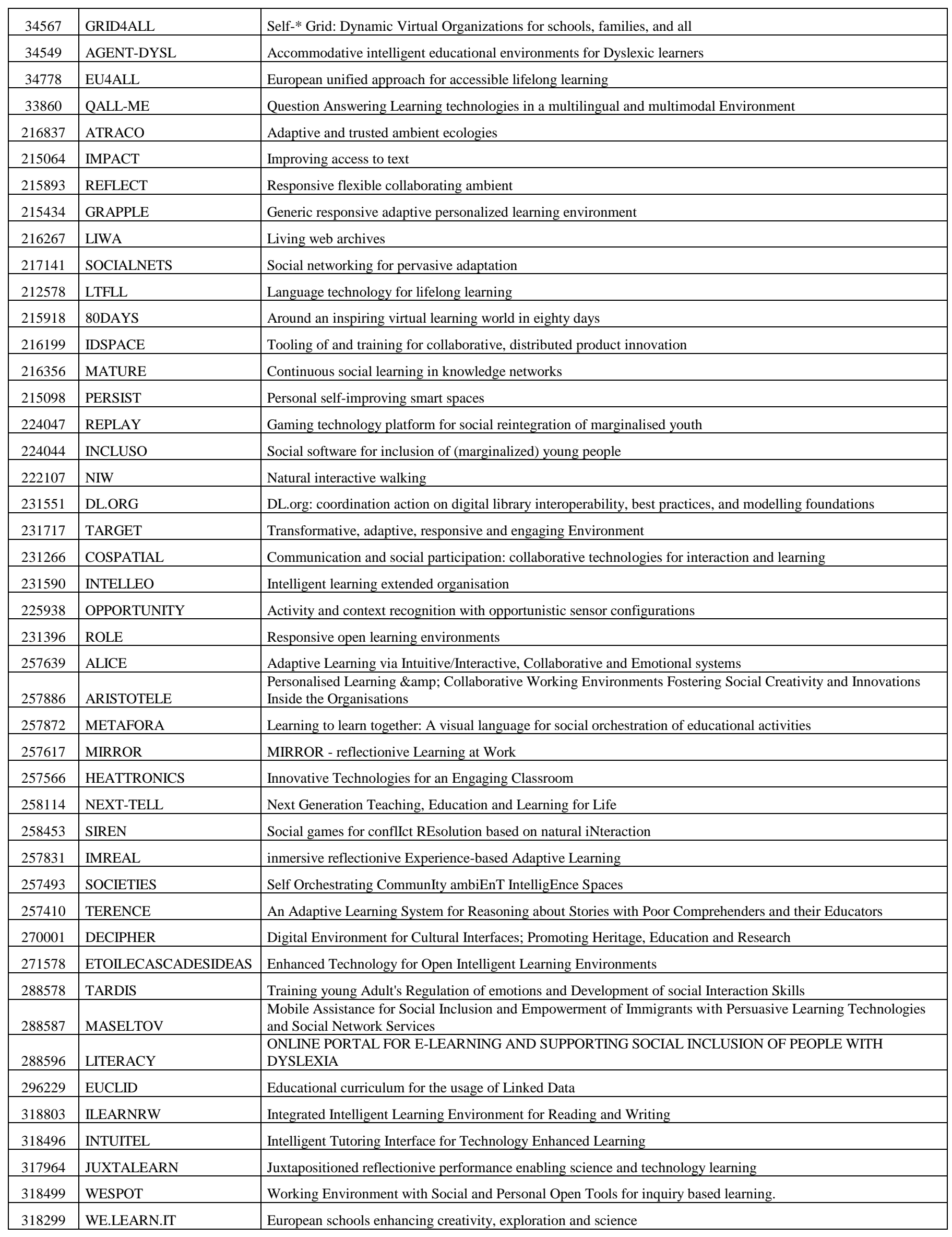

